\title{
Penentuan Harga Pokok Produk (HPP) dan Analisis Keuntungan Usahatani Tomat di Kelurahan Teluk Lingga Kabupaten Kutai Timur
}

\author{
Muzizat Akbarrizki \\ ${ }^{1}$ Program Studi Agribisnis, Sekolah Tinggi Pertanian Kutai Timur \\ Jl. Soekarno-Hatta No. 1 Sangatta, Kab. Kutai Timur, Kalimantan Timur \\ Email: muzizat_akbarrizki@stiperkutim.ac.id
}

\begin{abstract}
This study aims to determine the production cost of tomato and the rate of profit in Teluk Lingga, Sangatta. This study was conducted from March to August. The method used was a survey method. Data collected included primary and secondary. Determination of sample using census method, so that the sample were 10 farmers. The analysis used is analysis of farm income and the $R / C$ ratio. The results showed that cost of product is Rp. 3,261.54/kg, farming costs consist of fixed cost depreciation tool Rp. 594,958.00 and variable cost production Rp. 983,117.00 and labor Rp. $700,000.00$. Farm income is $R p .3,316,925.00$ and is based on the value of $R / C$ ratio = 2.4 so that tomato farming profitable and feasible to be developed.
\end{abstract}

Key Words: Cost of Product, income, tomato.

\section{ABSTRAK}

Penelitian ini bertjuan untuk mengetahui besarnya harga pokok produk usahatani tomat dan tingkat keuntungan usahatani tomat di Kelurahan Teluk Lingga. Penelitian ini dilaksanakan pada bulan Maret sampai dengan Agustus. Metode yang digunakan adalah metode survey. Data yang dikumpulkan meliputi data primer dan skunder. Penentuan sampel petani menggunakan metode sensus sehingga sampel adalah 10 petani. Analisis yang digunakan adalah analisis pendapatan dan R/C Ratio. Hasil penelitian menunjukan harga pokok produk adalah Rp. 3.261,54/kg, biaya usaha tani terdiri dari biaya tetap penyusutan alat Rp. 594.958,00 dan biaya tidak tetap biaya produk Rp. 983.117,00 dan tenaga kerja Rp. 705.000,00. Pendapatan usahatani adalah $\mathrm{Rp}$. 3.316.925 dan berdasrkan nilai $\mathrm{R} / \mathrm{C}$ ratio $=2,4$ sehingga usahatani tomat menguntungkan dan layak untuk dikembangkan.

Kata kunci: Harga pokok produk, pendapatan, tomat

\section{Pendahuluan}

\section{$1.1 \quad$ Latar Belakang}

Meningkatnya pertambahan penduduk di Indonesia dan seiring dengan meningkatnya kesadaran masyarakat akan pentingnya kesehatan serta pemenuhan gizi, maka kebutuhan akan makanan dan minuman yang mengandung banyak gizi juga semakin meningkat tajam. Pertanian memegang peranan penting dari keseluruhan perekonomian nasional. Hal ini dapat dilihat dengan banyaknya penduduk atau tenaga kerja yang hidup dan bekerja pada sektor pertanian. Bisa kita lihat dari peranan sektor pertanian terhadap penyediaan pangan dan penyumbang devisa Negara melalui ekspor dan lain sebagainya.

Pembangunan pertanian yang berhasil dapat diartikan jika terjadi pertumbuhan sektor ekonomi yang tinggi dan sekaligus terjadi perubahan masyarakat dan taraf hidup yang kurang baik menjadi lebih baik. Pertanian juga sebagai jenis usaha atau kegiatan 
ekonomi berupa penanaman atau usahatani (pangan, hortikultura, perkebunan, kehutanan, peternakan dan perikanan).

Buah tomat sebagai salah satu komoditas sayuran mempunyai prospek pemasaran yang cerah. Hal ini dapat dilihat dari banyaknya buah tomat yang dapat dimanfaatkan oleh masyarakat diantaranya adalah sebagai sumber vitamin dan juga untuk dikonsumsi dalam bentuk olahan, misalnya untuk minuman sari buah tomat, es juice tomat, dan konsentrat. Berbagai macam kegunaan tersebut dapat memberikan keuntungan, baik bagi konsumen, produsen, maupun masyarakat pada umumnya.

Kebutuhan minimum vitamin A dan vitamin $\mathrm{C}$ setiap orang dapat terpenuhi apabila tiap hari makan tomat sebanyak 100-300 gram. Akan tetapi sayuran dan buah-buahan lainnya merupakan sumbangan terhadap kebutuhan kita pula, sehingga apabila makan sayuran dan buah-buahan tersedia setiap hari telah cukup dapat menciptakan masyarakat yang sehat gizi.

Selain sebagai buah segar yang langsung dapat konsumsi, buah tomat juga dimanfaatkan untuk berbagai industri misalnya sambal, saos, minuman, jamu, dan kosmetik. Sebagai bahan makanan, kandungan gizi buah tomat untuk terapi pengobatan alami, buah tomat berkhasiat untuk mencegah dan mengobati radang usus buntu, membantu penyembuhan luka, mengobati jerawat, mencegah pembentukan batu empedu pada saluran kencing, menjaga stamina dan mengobati penyakit yang disebabkan kekurangan vitamin $\mathrm{C}$.

Potensi pasar buah tomat juga dapat dilihat dari segi harga yang terjangkau oleh seluruh lapisan masyarakat sehingga membuka peluang yang lebih besar terhadap serapan pasar. Termasuk potensi pasar untuk memenuhi kebutuhan tomat di Kabupaten Kutai Timur khususnya di wilayah kota Sangatta. Kelurahan Teluk Lingga sebagai wilayah pusat perdagangan dan pemerintahan di Kutai Timur mempunyai jumlah penduduk yang besar dan berpotensi menyerap komoditi pertanian sebagai bahan pangan termasuk komoditi tomat.

Berdasarkan data yang diperoleh secara lansung di lapangan bahwa terdapat 10 (sepuluh) orang petani yang mengusahakan komoditi tomat di Kelurahan Teluk Lingga pada saat dilakukan penelitian. Peneliti melihat bahwa usahatani ini mempunyai peluang untuk dikembangkan karena kebutuhan tomat bisa dipenuhi dari wilayah terdekat yang bisa memangkas biaya transportasi dibandingkan dengan harus mendatangkan dari luar Sangatta. Adapun terkadang petani belum memahami keputusan ekonomis dalam usahataninya, yang dimaksud adalah penggunaan faktor produk seefektif mungkin agar manajemennya lebih baik dan menguntungkan.

Oleh karena itu, peneliti tertarik untuk mengetahui harga pokok produk dan tingkat keuntungan usahatani komoditi tomat dengan menganalisis aspek usahatani seperti 
aspek faktor produk, biaya, harga, penerimaan, sehingga dapat diketahui tingkat pendapatan yang didapat dari usahatani dan menilai kelayakan komoditi tomat khususnya yang ada di lokasi penelitian yaitu Kelurahan Teluk Lingga.

\subsection{Perumusan Masalah}

1. Berapa besar harga pokok produk usahatani tomat per musim tanam di Kelurahan Teluk Lingga Kabupaten Kutai Timur?

2. Berapa keuntungan usahatani tomat di Kelurahan Teluk Lingga Kabupaten Kutai Timur?

\subsection{Tujuan Penelitian}

a. Mengetahui besarnya harga pokok produk usahatani tomat di Kelurahan Teluk Lingga Kabupaten Kutai Timur.

b. Mengetahui keuntungan usahatani tomat di Kelurahan Teluk Lingga Kabupaten Kutai Timur.

\subsection{Manfaat Penelitian}

a. Diharapkan hasil dari penelitian ini dapat menambah pengetahuan petani akan pengembangan usahatani, khususnya budidaya tomat.

b. Memberi informasi atau bahan penelitian lebih lanjut bagi peneliti lain yang berminat meneliti masalah yang erat hubungannya dengan topik ini.

c. Membantu memberikan data-data ilmiah tentang aspek-aspek yang masuk dalam usahatani komoditi tomat kepada pihak-pihak terkait, penentu kebijaksanaan sehingga diharapkan dapat dijadikan sebagai bahan pertimbangan dalam menentukan keputusan pembangunan pertanian.

\section{Metode Penelitian}

\subsection{Waktu dan Tempat}

Penelititan ini dilaksanakan selama 4 bulan, dimulai pada bulan Maret sampai dengan bulan Juni 2017. Lokasi penelitian di Kelurahan Teluk Lingga Kecamatan Sangatta Utara Kabupaten Kutai Timur.

\subsection{Metode Pengumpulan Data}

Data yang diperlukan dalam penelitian ini adalah data primer dan data sekunder, data primer diperoleh dengan cara pengamatan langsung (observasi), yaitu melakukan pengamatan secara langsung terhadap objek yang akan diteliti yaitu kegiatan usahatani tomat dan dengan cara wawancara, yaitu melalui komunikasi langsung dengan petani yang melakukan usahatani tomat di Kelurahan Teluk Lingga. Pengumpulan data dan informasi menggunakan daftar pertanyaan (quesioner) yang telah disusun oleh peneliti sesuai dengan tujuan penelitian. 
Sedangkan data sekunder yaitu data penunjang yang diperoleh dari studi kepustakaan berupa jurnal dari penelitian terkait sebelumnya, instansi terkait yaitu Kantor Kelurahan Teluk Lingga Kabupaten Kutai Timur dan sumber lain yang bisa menunjang penelitian ini.

\subsection{Metode Pengambilan Sampel}

Jumlah petani tomat menurut aparat penyuluh dan peneliti ketika survey lansung bahwa pada periode saat ini terdapat 10 (sepuluh) petani. Dikarenakan jumlah sampel kurang dari 100, maka pengambilan sampel dilakukan dengan menggunakan metode sensus yang mana peneliti mengambil keseluruhan petani tomat di Desa Teluk Lingga untuk dijadikan sebagai sampel.

\subsection{Definisi Variabel dan Pengukurannya}

Agar diperoleh pengertian serta batasan yang lebih jelas mengenai apa yang akan diteliti sesuai dengan konsep yang telah dikemukakan, maka secara operasional dapat dijabarkan sebagai berikut:

a. Biaya adalah seluruh biaya yang dikeluarkan untuk menjalankan proses usahatani tomat yaitu :

Biaya tetap (Fixed Cost), meliputi biaya penyusutan alat yang diperoleh dengan cara menghitung harga pembelian alat dibagi dengan umur teknis alat yang bersangkutan $(\mathrm{Rp})$.

Biaya tidak tetap (Variabel Cost), meliputi biaya sarana produk (benih, pupuk, pestisida) dan biaya tenaga kerja $(\mathrm{Rp})$

b. Produk adalah hasil dari usahatani tomat dalam satu kali musim tanam (kg).

c. Harga pokok produk adalah sumber ekonomi yang diukur dengan uang yang telah terjadi untuk memperoleh aktiva atau secara tidak langsung memperoleh penghasilan $(\mathrm{Rp})$.

d. Harga jual adalah nilai jual hasil produk usahatani tomat yang berlaku saat penelitian ( $\mathrm{Rp})$.

e. Penerimaan usahatani adalah jumlah yang diterima petani dari suatu proses produk, dimana penerimaan tersebut didapatkan dengan mengalikan produk dengan harga yang berlaku dan dinyatakan dalam bentuk uang sebelum dikurangi dengan biaya-biaya pengeluaran selama kegiatan usahatani ( $R p)$.

f. Pendapatan adalah selisih antara pendapatan kotor (total penerimaan) dengan total biaya $(\mathrm{Rp})$.

g. $\mathrm{R} / \mathrm{C}$ ratio adalah ukuran tingkat pendapatan usahatani tomat dengan menghitung perbandingan antara penerimaan dan biaya yang diperoleh dengan membagi total penerimaan (TR) dengan total biaya (TC). 


\subsection{Metode Analisis Data}

a. Menurut Soekirno (2006), biaya total (TC) adalah keseluruhan biaya produk yang dikeluarkan. Biaya produk total didapat dari menjumlahkan total biaya tetap (TFC) dengan total biaya variable (TVC). Dengan demikian biaya total dapat dihitung dengan menggunakan rumus berikut:

$$
\mathrm{TC}=\mathrm{TFV}+\mathrm{TVC}
$$

$\begin{array}{lll}\text { Keterangan : } & \text { TC } & \text { : Total biaya (Total Cost) } \\ & \text { TFC } & \text { : Total Biaya Tetap (Total Fixed Cost) } \\ & \text { TVC } & \text { : Total Biaya Variabel (Total Varibel Cost) }\end{array}$

b. Menurut Mulyadi (2000), bahwa harga pokok produk menurut metode full costing terdiri dari :

$\begin{array}{ll}\text { Biaya bahan baku } & R p x x x \\ \text { Biaya tenaga kerja langsung } & R p x x x \\ \text { Biaya overhead pabrik tetap } & R p x x x \\ \text { Biaya overhead pabrik variabel } & R p x x x \\ \text { Harga pokok produk } & R p x x x\end{array}$

c. Menurut Soekartawi (2006), penerimaan usahatani adalah perkalian antara produk yang diperoleh dengan harga jual. Pernyataan ini dapat dituliskan sebagai berikut:

$$
\mathrm{TR}=\mathrm{P} \times \mathrm{Q}
$$

$$
\begin{array}{lll}
\text { Keterangan : } & \text { TR } & \text { : Total penerimaan (Total Revenue) } \\
& \mathrm{P} & \text { : Harga (price) } \\
\mathrm{Q} & \text { : Produk yang diperoleh dalam suatu usahatani (Quantity) }
\end{array}
$$

d. Untuk menghitung pendapatan digunakan konsep pendapatan yang dikemukakan oleh (Soedarsono, 2004), yaitu cara mengurangkan total penerimaan dengan total biaya, dengan rumus sebagai berikut:

$$
\mathrm{I}=\mathrm{TR}-\mathrm{TC}
$$

$$
\begin{array}{lll}
\text { Keterangan : } & \text { I } & \text { : Pendapatan (Income) } \\
& \text { TR } & \text { : Total Penerimaan (Total Revenue) } \\
& \text { TC } & \text { : Total Biaya (Total Cost) }
\end{array}
$$

e. R/C ratio adalah suatu teknik analisa kelayakan untuk mengukur perbandingan antara total penerimaan dan total biaya dari suatu produk (Ibrahim, 2003) yang dapat dihitung melalui persamaan sebagai berikut:

$$
\begin{array}{lll}
\mathrm{R} / \mathrm{C} \text { RATIO }= & \text { TR } / \mathrm{TC} \\
\text { Keterangan : } & \text { TR } & \\
& \text { TC } & : \text { Total penerimaan }(\text { Total Revenue }) \\
& : \text { Total biaya }(\text { Total Cost) }
\end{array}
$$

Kriteria penilaian $\mathrm{R} / \mathrm{C}$ ratio:

$$
\begin{array}{ll}
R / C<1 & : \text { Usaha mengalami kerugian. } \\
R / C=1 & : \text { Usaha mencapai titik impas. } \\
R / C>1 & : \text { Usaha mengalami keuntungan. }
\end{array}
$$

\section{Hasil dan Pembahasan}

\subsection{Keadaan Umum Lokasi Penelitian}

\subsubsection{Luas dan letak geografis}


Sebagai salah satu kelurahan yang tergabung dalam wilayah administratif Kabupaten Kutai Timur, Kelurahan Teluk Lingga secara geografis berbatasan dengan :

- Sebelah Utara berbatasan dengan Desa Singa Gembara

- Sebelah Timur berbatasan dengan Selat Makassar

- Sebelah Selatan berbatasan dengan Sangatta Utara

- Sebelah Barat berbatasan dengan Sungai/TNK

Secara Umum keadaan topografi Kelurahan Teluk Lingga bearada pada dataran rendah, berbukit-bukit dan kawasan rawa. Luas wilayah Kelurahan Teluk Lingga adalah $2.977 \mathrm{Ha}$ dan berada di $0-50 \mathrm{~m}$ dpl dengan suhu udara berkisar $28^{\circ} \mathrm{C}$. Iklim salah satu faktor yang mempengaruhi di Kelurahan Teluk Lingga dengan curah hujam $22 \mathrm{~mm}$ serta kelembapan $75-80 \%$ suhu ata-rata $28^{\circ} \mathrm{C}$. Tekstur tanah di Kelurahan Teluk Lingga lempung dengan tanah warna kuning.

\subsubsection{Keadaan penduduk}

\section{a. Penduduk berdasarkan jenis kelamin}

Jumlah penduduk Kelurahan Teluk Lingga pada akhir tahun 2015 adalah sebanyak 24.377 jiwa, dengan jumlah penduduk laki-laki dewasa 12.075 jiwa yaitu setara dengan 51,39\%, jumlah penduduk perempuan 12.229 atau setara dengan 48,61\%. Jumlah penduduk di Kelurahan Teluk Lingga berdasarka gender bisa dilihat di Tabel.1 berikut ini

Tabel 1. Jumlah Penduduk dikelurahan Teluk Lingga

\begin{tabular}{clcc}
\hline No & \multicolumn{1}{c}{ Jenis Kelamin } & Jumlah Jiwa & Persentase (\%) \\
\hline 1 & Laki-laki & 12.075 & 49,68 \\
2 & Perempuan & 12.229 & 50,31 \\
\hline & Jumlah & 24.304 & 100
\end{tabular}

Sumber: Kantor Desa Kelurahan Teluk Lingga (2014)

\section{b. Penduduk berdasarkan mata pencaharian}

Jumlah penduduk di Kelurahan Teluk Lingga berdasarkan mata pencaharian dapat dilihat pada Tabel 2.

Tabel 2. Jumlah Penduduk Teluk Lingga Menurut Mata Pencaharian

\begin{tabular}{lcc}
\hline \multicolumn{1}{c}{ Mata Pencaharian } & Jumlah (jiwa) & Presentase (\%) \\
\hline Petani & 486,08 & 2 \\
Buruh & 3645,6 & 15 \\
Pedagang & 4860,8 & 20 \\
PNS & 2430,4 & 10 \\
TNI/POLRI & 972,16 & 4 \\
Pegawai Swata & 7291,2 & 30 \\
Wiraswasta & 3645,6 & 15 \\
Lain-lain & 972,16 & 4 \\
\hline Jumlah & 24.304 & 100
\end{tabular}

Dapat dilihat dari Tabel 2, bahwa mata pencaharian sebagai petani yaitu berkisar $2 \%$, dari sekian data tersebut di atas ada 10 orang petani yang mengusahakan tanaman 
tomat, pada saat penelitian dilakukan. Jumlah tersebut bisa dikatakan kurang untuk memenuhi kebutuhan di Kecamatan Sangatta Utara.

\subsection{Karakteristik Responden}

Karakteristik responden merupakan gambaran secara umum latar belakang petani usahatani tomat. Petani tomat yang menjadi responden dalam penelitian ini adalah sebanyak 10 orang.

\subsubsection{Usia responden}

Berdasarkan hasil pengolahan data responden dalam penelitian ini usia petani tomat berkisar antara 32-55. Usia merupakan faktor yang mempengaruhi efektivitas kerja petani dalam mengelola usahataninya sehingga dapat mempengaruhi produk dan pendapatan yang diperolehnya. Usia paling produktif yaitu berkisar dari 39-49 tahun.

Tabel 3. Klasifikasi Responden Usahatani Tomat berdasarkan Umur

\begin{tabular}{cccc}
\hline No & Umur (tahun) & Jumlah (orang) & Presentase (\%) \\
\hline 1 & $32-39$ & 3 & 30 \\
2 & $39-49$ & 5 & 50 \\
3 & $49-59$ & 2 & 20 \\
\hline \multicolumn{7}{l}{ Sumber: Data Primer (diolah) 2017 } & 10 & 100 \\
\hline
\end{tabular}

\subsubsection{Pendidikan responden}

Tingkat pendidikan merupakan faktor yang penting bagi petani dalam melakukan usaha taninya. Pendidikan dapat berpengaruh lansung dalam kemudahan dalam mengadopsi teknologi terapan yang berkembang dalam usahataninya, walaupun pendidikan yang petani miliki tidak didapat sepenuhnya dari pendidikan formal melainkan lebih banyak diperoleh melalui eksperimen atau pengalaman dan belajar lansung kepada penyuluh dan teman-teman yang telah sukses. Pendidikan petani tomat yang paling dominan adalah tingkat SD sebanyak 6 jiwa sedangkan SMP sebanyak 2 jiwa dan sisanya SMA 2 jiwa. Secara rinci dapat dilihat pada Tabel 4.

Tabel 4. Presentasi Tingkat Pendidikan Responden Usahatani Tomat di Kelurahan Teluk Lingga

\begin{tabular}{cccc}
\hline No & Tingkat pendidikan & Jumlah & Presentase (\%) \\
\hline 1 & SD & 6 & 60 \\
2 & SMP & 2 & 20 \\
3 & SMA & 2 & 20 \\
\hline Jumlah & & 10 & 100 \\
\hline
\end{tabular}

Sumber: Data Primer (diolah) 2017

\subsubsection{Luas dan Kepemilikan Lahan}

Lahan usahatani petani tomat merupakan faktor pendukung yang cukup berpengaruh pada hasil produk tomat. Luas lahan yang diusahakan oleh responden petani tomat dalam penelitian di Kelurahan Teluk Lingga antara 0,25 sampai 0,50 ha. Keadaan luas lahan yang dimiliki oleh petani ditunjukan pada Tabel 5. 
Tabel 5. Luas Lahan Usahatani Tomat di Kelurahan Teluk Lingga

\begin{tabular}{ccccc}
\hline No & Luas Laha $\left(\mathrm{m}^{2}\right)$ & Jumlah Responden & Persentase (\%) & Status Kepemilikan Lahan \\
\hline 1 & 400 & 1 & 10 & Pinjam Pakai \\
2 & 500 & 2 & 20 & Pinjam Pakai \\
3 & 700 & 2 & 20 & Pinjam Pakai \\
4 & 1.000 & 5 & 50 & Pinjam Pakai \\
\hline Jumlah & 2.600 & 10 & & \\
\hline \multicolumn{2}{l}{ Sumber: Data Primer Setelah Diolah (2017) }
\end{tabular}

\subsection{Biaya Produk Usahatani Tomat}

\subsubsection{Biaya tetap (fixed cost)}

Tabel 7. Rincian Rata-Rata Biaya Penyusutan Peralatan 10 Responden per Musim Tanam

\begin{tabular}{ccccccccc}
\hline $\begin{array}{c}\text { No. } \\
\begin{array}{c}\text { Respon } \\
\text { den }\end{array}\end{array}$ & $\begin{array}{c}\text { Gembor } \\
(\mathrm{Rp})\end{array}$ & $\begin{array}{c}\text { Parang } \\
(\mathrm{Rp})\end{array}$ & $\begin{array}{c}\text { Cangkul } \\
(\mathrm{Rp})\end{array}$ & $\begin{array}{c}\text { Sprayer } \\
(\mathrm{Rp})\end{array}$ & $\begin{array}{c}\text { Pompa Air } \\
(\mathrm{Rp})\end{array}$ & $\begin{array}{c}\text { Selang } \\
(\mathrm{Rp})\end{array}$ & $\begin{array}{c}\text { Ember } \\
(\mathrm{Rp})\end{array}$ & $\begin{array}{c}\text { Sabit } \\
(\mathrm{Rp})\end{array}$ \\
\hline 1 & 12.000 & 40.000 & 16.250 & 71.250 & 250.000 & 26.666 & 12.000 & 10.000 \\
2 & 9.500 & 30.000 & 32.500 & 96.250 & 500.000 & 33.333 & 10.000 & 16.250 \\
3 & 9.667 & 32.500 & 30.833 & 71.250 & 250.000 & 66.667 & 15.000 & 10.000 \\
4 & 24.500 & 38.333 & 26.250 & 71.250 & 325.000 & 8.333 & 10.500 & 12.500 \\
5 & 14.000 & 40.000 & 21.250 & 97.500 & 500.000 & 23.333 & 8.000 & 10.000 \\
6 & 10.750 & 32.500 & 46.250 & 96.250 & 216.666 & 40.000 & 8.000 & 12.500 \\
7 & 12.000 & 40.000 & 30.833 & 97.500 & 250.000 & 70.000 & 8.000 & 12.500 \\
8 & 14.000 & 40.000 & 19.167 & 171.250 & 450.000 & 41.667 & 5.000 & 12.500 \\
9 & 14.500 & 32.500 & 21.250 & 121.250 & 500.000 & 83.333 & 8.000 & 13.750 \\
10 & 12.000 & 32.500 & 46.250 & 71.250 & 300.000 & 50.000 & 10.500 & 12.500 \\
\hline Jumlah & 132.917 & 358.333 & 290.833 & 965.000 & 3.541 .666 & 443.333 & 95.000 & 122.500 \\
\hline $\begin{array}{c}\text { Rata- } \\
\text { rata }\end{array}$ & 13.291 & 35.833 & 29.083 & 96.500 & 354.166 & 44.333 & 9.500 & 12.250 \\
\hline
\end{tabular}

Biaya tetap merupakan biaya yang tidak berubah dengan peningkatan atau penurunan jumlah produk yang dihasilkan. Biaya penyusutan alat merupakan pengurangan nilai suatu alat oleh karena berlalunya waktu. Pada keadaan biasa, dengan peralatan lapang yang hanya dipakai beberapa hari per tahun. Suatu alat bisa menjadi kadaluarsa dikarenakan adanya model baru yang lebih canggih, perubahan cara bertani dan sebagainya. Alat-alat pertanian yang digunakan dalam usahatani tomat dapat dilihat pada Tabel 7.

Nilai penyusutan alat merupakan nilai yang terdapat pada suatu alat dengan melihat harga awal dari barang tersebut, harga akhir, umur teknis pemakaian dan jumlah barang tersebut. Jumlah biaya penyusutan alat yang dikeluarkan oleh 10 responden petani tomat sebagaimana. Perincian pada tabel di atas dapat kita ketahui bahwa ratarata penyusutan alat usahatani tomat per musim tanam adalah sebesar Rp. 594.958,00.

\subsubsection{Biaya tidak tetap (variabel cost)}

Biaya tidak tetap merupakan biaya yang dapat berpengaruh lansung terhadap tingkat produk yang di keluarkan. 


\section{Biaya Sarana Produksi}

Biaya sarana produksi dapat digolongkan atas dasar hubungan perubahan volume produksi adapun biaya produk terdiri dari biaya benih, pupuk, dan pestisida bisa dilihat pada Tabel 8. Rata-rata biaya sarana produk usahatani tomat yaitu Rp. 983.117,00. Pemakaian benih, pupuk dan pestisida yang cukup beragam tergantung dari hama dan penyakit serta luas lahan masing-masing responden. Perlu adanya penekanan pada biaya produksi karena dilihat dari perincian perhitungan biaya pada benih dan pupuk cukup besar. Petani usahatani tomat bisa membuat bibit sendiri untuk masa tanam berikutnya ataupun untuk pestisida bisa lebih hemat dengan membuat pestisida nabati.

Tabel 8. Biaya Variabel Rata-rata Benih, Pupuk dan Pestisida Usahatani Tomat per Musim Tanam

\begin{tabular}{clcccc}
\hline No & Sarana Produk & Jumlah & Satuan & Harga (Rp) & Total (Rp) \\
\hline 1 & Benih & 1,7 & $\mathrm{Kg}$ & 65.000 & 110.500 \\
\hline 2 & & \multicolumn{3}{c}{ Pupuk } \\
\hline & Pupuk Kandang & 11,5 & $\mathrm{Kg}$ & 17.250 & 19.8375 \\
& Dolomit & 13 & $\mathrm{Kg}$ & 13.000 & 169.000 \\
& Urea & 3,5 & $\mathrm{Kg}$ & 7.000 & 24.500 \\
& KNO & 2,3 & $\mathrm{Kg}$ & 45.600 & 104.880 \\
& Poska & 1,8 & $\mathrm{Kg}$ & 14.400 & 25.920 \\
& TSP & 2 & $\mathrm{Kg}$ & 50.000 & 100.000 \\
\hline 3 & & Pestisida & & \\
\hline & Prevaton & 0,8 & Liter & 111.400 & 89.120 \\
& Kanon & 0,4 & Liter & 14.000 & 5.600 \\
& Vegasus & 0,55 & Liter & 43.000 & 23.650 \\
& Gandasil & 0,65 & Kg & 22.250 & 14.462 \\
& Linse & 0,8 & Liter & 19.700 & 15.760 \\
& Atonic & 0,6 & Liter & 24.000 & 14.400 \\
& Winder & 0,4 & Liter & 24.000 & 9600 \\
\hline & & & & 983.117 \\
\hline
\end{tabular}

Biaya Tenaga Kerja

Biaya tenaga kerja yang diperhitungkan dalam penelitian ini adalah biaya tenaga kerja untuk setiap kegiatan usahatani tomat pada setiap kegiatan usahatani yang harus dibayar untuk tenaga kerja yang digunakan selama satu musim tanam pada Tabel 9.

Tabel 9. Analisis Biaya Tenaga Kerja Usahatani Tomat per Musim Tanam

\begin{tabular}{ccccc}
\hline No. Responden & TK & HOK & Upah/hari (Rp) & Total Biaya (Rp/Periode) \\
\hline 1 & 1 & 8 & 90.000 & 720.000 \\
2 & 2 & 4 & 85.000 & 680.000 \\
3 & 1 & 9 & 80.000 & 720.000 \\
4 & 1 & 8 & 90.000 & 720.000 \\
5 & 1 & 8 & 90.000 & 720.000 \\
6 & 2 & 4 & 80.000 & 640.000 \\
7 & 1 & 8 & 85.000 & 680.000 \\
8 & 2 & 4 & 90.000 & 720.000 \\
9 & 1 & 9 & 90.000 & 810.000 \\
10 & 1 & 8 & 80.000 & 640.000 \\
\hline Jumlah & 13 & 70 & 860.000 & 7.050 .000 \\
\hline Rata-rata & & 7 & 86.000 & 705.000 \\
\hline
\end{tabular}

Tenaga kerja usahatani tomat untuk tiap responden rata-rata adalah 7 HOK dengan upah rata-rata Rp. $86.000,00$ per hari. Sehingga total biaya upah tenaga kerja yang 
dikeluarkan oleh petani tomat per musim tanam adalah sebesar Rp. 7.050.000,00 dengan rata-rata Rp. 705.000,00 per responden. Biasanya tenaga kerja sangat dibutuhkan pada waktu pengolahan tanah sampai penanaman dan pada waktu panen dan pasca panen, dari semua responden semua menggunakan tenaga kerja laki-laki.

\subsection{Harga Pokok Produk}

Menurut Mulyadi (1999), bahwa harga pokok produk menurut metode full costing pada 10 responden dengan rata-rata biaya yang dikeluarkan setiap musim tanamnya adalah sebagai berikut

Biaya bahan baku

Biaya tenaga kerja langsung

Biaya overhead pabrik tetap

Biaya overhead pabrik variabel

Harga pokok produk
Rp. $110.500,00$

Rp. $705.000,00$

Rp. $594.958,00$

$\frac{\text { Rp. } 872.617,00+}{\text { Rp. } 2.283 .075,00}$

Dari perhitungan harga pokok produksi dengan metode full costing maka dapat diketahui bahawa rata-rata harga pokok produksi setiap responden adalah $\mathrm{Rp}$. 2.283.075,00. Dengan mengetahui jumlah unit produksi rata-rata responden 700 $\mathrm{kg} /$ musim tanam, maka dapat diketahui harga pokok produk per $\mathrm{kg}$ per musim tanam dengan menggunakan metode kalkulasi bagi adalah sebagai berikut:

Harga Pokok Produk $/ \mathrm{kg}=\frac{R p \cdot \frac{2203.075,00}{\text { mush }} \text { tonam }}{700 \mathrm{~kg}}=R p .3 .261,54 / \mathrm{kg} / \mathrm{musim}$ tanam

\subsection{Penerimaan}

Penerimaan adalah satuan rupiah yang diterima petani responden berdasarkan jumlah produksi tomat dikalikan dengan harga yang berlaku di tingkat petani. Secara rinci dapat dilihat pada Tabel 10.

Tabel 10. Jumlah Hasil Produksi Usahatani Tomat per Musim Tanam

\begin{tabular}{cccc}
\hline No. Responden & Jumlah $(\mathrm{kg})$ & Harga $(\mathrm{Rp} / \mathrm{kg})$ & Penerimaan $(\mathrm{Rp})$ \\
\hline 1 & 700 & 8.000 & 5.600 .000 \\
2 & 900 & 8.000 & 7.200 .000 \\
3 & 500 & 8.000 & 4.000 .000 \\
4 & 700 & 8.000 & 5.600 .000 \\
5 & 600 & 8.000 & 4.800 .000 \\
6 & 800 & 8.000 & 6.400 .000 \\
7 & 600 & 8.000 & 4.800 .000 \\
8 & 1000 & 8.000 & 8.000 .000 \\
9 & 600 & 8.000 & 4.800 .000 \\
10 & 600 & 8.000 & 4.800 .000 \\
\hline Jumlah & 7000 & & 56.000 .000 \\
\hline Rata-rata & 700 & 8.000 & 5.600 .000 \\
\hline
\end{tabular}

Jumlah hasil produk usahatani di Kelurahan Teluk Lingga sebesar $7000 \mathrm{~kg}$ dengan rata-rata $700 \mathrm{~kg}$ tiap responden. Masing-masing hasil produk berbeda-beda, cara budidaya, luas lahan, dan sarana produk menjadi faktor yang mempengaruhi hasil produk. Harga jual pada saat masa penelitian harga tomat sedang turun yaitu berkisar 
pada Rp. 8.000,00 harga tersebut merupakan harga dari tengkulak karena untuk menghemat biaya tranportasi sehingga semua responden yang terdapat di lapangan pada saat penelitian hanya menggunakan sistem pemasaran satu jalur. Panen terbesar terjadi pada saat proses pemanenan ke 5-6, panen pertama cukup rendah dikarenakan hasil produksi belum terlalu maksimal.

\subsection{Pendapatan}

Pendapatan usahatani adalah penerimaan dikurangi dengan jumlah biaya produksi. Total penerimaan,total biaya produksi dan pendapatan rata-rata petani tomat di Kelurahan Teluk Lingga terinci pada Tabel 11.

Tabel 11. Pendapatan Usahatani Tomat per Musim Tanam

\begin{tabular}{|c|c|c|}
\hline No & Uraian & Jumlah (Rp) \\
\hline 1 & Penerimaan & 5.600 .000 \\
\hline 2 & Biaya produk & 2.283 .075 \\
\hline & Pendapatan & 3.316 .925 \\
\hline
\end{tabular}

Hasil pendapatan rata-rata responden usahatani tomat di Kelurahan Teluk Lingga dapat diketahui dengan penerimaan sebesar Rp. 5.600.000,00 dan biaya produk sebesar Rp. 2.283.075,00 per periode adalah Rp. 3.316.925,00 dengan jumlah tersebut diatas pendapatan responden usahatani tomat per bulannya yaitu Rp. 552. 821,00. Jika diasumsikan tentu saja tidak mencukupi untuk kebutuhan perbulannya setiap responden dengan rata-rata tanggungan keluarga sebanyak 2 orang, tetapi usahatani tomat ini hanya dijadikan sebagai usaha sampingan untuk memenuhi kebutuhan hidup petani juga membudidayakan tanaman lainnya.

\subsection{R/C Ratio}

Suatu usaha dinilai menguntungkan jika $R / C$ rasio $>1$, yang merupakan dari perbandingan total penerimaan dengan jumlah total biaya yang dikeluarkan selama satu musim tanam. Perbandingannya dapat dilihat pada Tabel 12.

Tabel 12. Nilai R/C Ratio Usahatani Tomat per Musim Tanam

\begin{tabular}{|c|c|c|}
\hline No & Uraian & Jumlah (Rp) \\
\hline 1 & Total biaya produk & 2.283 .075 \\
\hline 2 & Total penerimaan & 5.600 .000 \\
\hline
\end{tabular}

Diketahui penerimaan usahatani tomat adalah Rp. 5.600 .000 dengan total biaya produk Rp. 2.283.075, perbandingan biaya dan penerimaan $\mathrm{R} / \mathrm{C}$ ratio didapat 2,4 yang menunjukkan bahwa $\mathrm{RC}$ ratio bernilai lebih besar daripada 1 maka dapat dikatakan bahwa usahatani yang dilakukan di Kelurahan Teluk Lingga tersebut adalah menguntungkan.

\section{Kesimpulan}

Harga pokok produk (HPP) rata-rata dari setiap responden adalah Rp. 2.283.075,00 per musim tanam atau Rp. $3.261,54 / \mathrm{kg} / \mathrm{musim}$ tanam. Penerimaan seluruh 
responden usahatani tomat di Kelurahan Teluk Lingga per musim tanam adalah Rp. $56.000 .000,00$. dengan rata-rata hasil produksi tiap responden adalah $700 \mathrm{~kg}$ maka ratarata penerimaan tiap responden adalah sebesar Rp. 5.600.000,00. Rata-rata pendapatan responden usahatani tomat di Kelurahan Teluk Lingga per musim tanam adalah sebesar Rp. 3.316.925,00, dengan jumlah tersebut maka diketahui pendapatan responden usahatani tomat per bulannya yaitu Rp. 552.821,00. Diketahui bahwa nilai R/C yang telah dianalisis didapat nilai R/C 2,4 yang lebih besar dari nilai 1 maka berarti bahwa usahatani tomat yang diusahakan di Kelurahan Teluk Lingga tersebut adalah menguntungkan.

Hasil pendapatan rata-rata seperti pada pembahasan di atas usahatani tomat hanya layak untuk dijadikan usaha sampingan karena harga tomat yang cukup rendah, tapi jika dibudidayakan dengan baik dan dengan lahan yang cukup besar bisa jadi sangat menguntungkan. Perlunya penekanan pada biaya produksi usahatani untuk memaksimalkan biaya produksi.

\section{Daftar Pustaka}

Cahyono, B. 1998. Tomat Budidaya dan Analisis Usaha Tani. Kanisius, Yogyakarta. Ibrahim, Yacob. 2003. StudiKelayakanBisnis (EdisiRevisi). RinekaCipta, Jakarta Mubyarto. 1994. Pengantar Ekonomi Pertanian. Edisi 3. LP3ES, Jakarta.

Mulyadi. 2000. Akuntansi Biaya. Penentuan Harga Pokok dan Pengendalian Biaya. Edisi 3. Badan Penerbit Fakultas Ekonomi Universitas Gadjah Mada. Yogyakarta.

Samuelson, P. A dan W. D Nordhaus. 2003. Ekonomi Mikro. Edisi 14. Erlangga, Jakarta. Soedarsono. 2004. Pengantar Ekonomi Mikro. LP3S, Jakarta.

Soekartawi. 1995. Analisis Usaha Tani. Jakarta : UI Press 2001. Pengantar Agroindustri. PT. Raja Grafindo Persada. Jakarta. 2006. Analisis Usahatani. UI Press, Jakarta.

Soekirno,S. 2006. Pengantar teori mikroekonomi. RajaGrafindo Persada, Jakarta. 2006. Mikro Ekonomi Teori Pengantar. Edisi ke Tiga Jakarta. Raja Grafindo Persada

Sukirno. 2003. Pengantar Teori Mikro Ekonomi (Edisi ke Tiga), Jakarta. PT. Salemba Empat. 